J. Bangladesh Acad. Sci., Vol. 42, No. 2, 121-128, 2018

DOI: https://doi.org/10.3329/jbas.v42i2.40039

\title{
IN VITRO SCREENING OF FUNGICIDES AND PLANT EXTRACTS AGAINST PATHOGENIC FUNGI ASSOCIATED WITH INFECTED FRUITS OF CARICA PAPAYA L.
}

\author{
REZUANA BINTE HELAL ${ }^{1}$ AND SHAMIM SHAMSI* \\ Department of Botany, University of Dhaka, Dhaka - 1000, Bangladesh
}

\section{ABSTRACT}

Five fungicides viz., Autostin 50 WDG, Dithane M 45, Greengel 72 WP, Ridomil Gold MZ 68 WG and Tilt 250 EC exclusively were tested against three pathogenic fungi viz., Colletotrichum gloeosporioides (Penz.) Sacc., Fusarium nivale (Fr.) Ces. and Fusarium sp. associated with Carica papaya L. following poisoned food technique. At $100 \mathrm{ppm}$ Autostin showed complete growth inhibition of C. gloeosporioides, F. nivale and Fusarium sp., while Tilt 250 EC showed complete growth inhibition of C. gloeosporioides at the same concentration. These fungicides at 400 and $500 \mathrm{ppm}$ showed complete growth inhibition of $F$. nivale. Tilt 250 EC showed complete growth inhibition of Fusarium sp. at 300, 400 and 500 ppm. Eight plants extract, viz., Adhatoda vasica, Azadirachta indica, Curcuma longa, Ocimum sanctum, Lantana camara, Tagetes erecta, Thuja orientalis and Vitex negundo were also tested for their efficacy at 5, 10, 15 and 20\% concentrations against these pathogenic fungi. Out of the eight plant extracts, Ocimum sanctum showed highest (88.57\%) radial growth inhibition of C. gloeosporioides at $20 \%$ concentration. Curcuma longa showed highest (88.55\%) radial growth inhibition of $F$. nivale and Adhatoda vesica showed highest (80.02\%) radial growth inhibition of Fusarium sp. at the same concentrations. The present investigation suggests Autostin 50 WDG and Tilt 250 EC as best inhibiting chemical fungicides for C. gloeosporioides, F. nivale and Fusarium sp. Extracts of O. sanctum, C. longa and Adhatoda vesica were found to be superior to other plant extracts tested.

Keywords: In vitro screening, Fungicides, Plant extracts, Pathogenic fungi, Carica papaya L.

\section{INTRODUCTION}

Papaya (Carica papaya L.) plant is known to have uterotonic, nephroprotective, antiinflamatory and anti-tumor properties (Milind and Gurditta 2011). Papaya is a good source of nutrient and vitamin A and C (Duke 1984). Glucose is the main sugar in papaya but sucrose content increases during ripening and can reach up to $80 \%$ of the total sugars (Parni and Verma 2014). The availability of the fruit is reduced due to high level of post-harvest loss (Mondal et al. 1995). Sawant and Gawri (2011) reported that fungal infection reduced the nutritional value of the fruits. Approximately $41 \%$ postharvest loss of papaya was recorded in Bangladesh (Hassan 2010). Various fungi cause rots in fruits of papaya.
Due to environmental concerns of controlling fungal disease by toxic chemicals, researchers have focused their efforts on developing alternative methods of controlling fungal diseases (Baker 1987, Cook 1993 and Heydari and Pessarakli 2010). One is use of biological antagonists and plant extracts. Plant extracts can be successfully exploited in modern agriculture which has recently attracted attention of several workers. Plant constituents have been reported to be successful fungitoxicants because of low phytotoxicity, systemicity, easy biodegradability and favorable effects for the growth of the host (Fawcett and Spencer 1970 and Panday et al. 1983). Extracts obtained from many plants have recently been studied for their antifungal

* Corresponding author: <prof.shamsi@gmail.com>.

${ }^{1}$ The experiment was conducted in the laboratory of Mycology and Plant Pathology,

Department of Botany, University of Dhaka, Dhaka - 1000, Bangladesh 
activities (Monoharachary and Reddy 1978, Ahmed and Sultan 1984, Miah et al. 1990, Hosen et al. 2016).

The present investigation was undertaken to evaluate the toxicity of some chemical and plant extracts against test pathogens.

\section{MATERIALS AND METHODS}

Infected ripe fruits of Carica papaya L. having characteristic symptoms were collected from five different markets of Dhaka City, during April and May, 2016 in separate sterile polyethylene bags, labeled properly and brought to the laboratory. The associated fungi were isolated following Tissue planting method on PDA medium (Anonymous 1968). Identification of the fungi were done following standard literature. Pathogenecity of the isolated fungi were done following fruit inoculation technique. Among the isolated fungi Colletotrichum gloeosporioides, Fusarium nivale and Fusarium sp. were found to be pathogenic to papaya fruit (Helal 2017). Five fungicides with different active ingredients, viz., Autostin WDG, Dithane M 45, Greengel 72 WP, Ridomil Gold MZ 68 WG and Tilt 250 EC were collected from the Krishi Upokoron Biponi Kendro at Khamarbari, Farmgate, Dhaka (Table 1). Of the five fungicides used in the present investigation, Autostin 50 WDG and Dithane M 45 are systemic while Tilt 250 EC and Greengel $72 \mathrm{WP}$ are protectant fungicides and Ridomil gold MZ $68 \mathrm{WG}$ is both systemic and protectant fungicide. For each fungicide, a stock solution having the concentrations of 10,000 ppm was prepared. The calculated amount of the stock solution of a fungicide was supplemented with sterilized PDA medium to get the conc. of 100, 200, 300, 400 and $500 \mathrm{ppm}$. In the control set required amount of sterile water instead of fungicide solution was added to the PDA medium.

A total of eight plants were selected for evaluating their effect on the radial growth of $C$. gloeosporioides, F. nivale and Fusarium sp. follwing Rai and Bashar (1991). The desired parts of each plant were thoroughly washed in tap water, air dried and then used for fresh extract preparation. The pulverized mass of a plant part was squeezed through four folds of fine cloth and the extracts were centrifuged at $3000 \mathrm{rpm}$ for 20 minutes to remove particulate matter. The supernatants were filtered through Whatman filter paper and the filtrate was collected in $250 \mathrm{~mL}$ Erlenmeyer flasks. In this method, the requisite amount of the filtrate of each plant extract was mixed with PDA medium to get $5,10,15$ and $20 \%$ concentratios.

Both the sets i.e. medium with fungicides or plant extracts thus prepared were poured into sterilized Petri plates and was allowed to solidify. Each Petri plate was inoculated centrally with a $5 \mathrm{~mm}$ agar disc cut from the margin of actively growing 7 day culture of the test pathogens. In the control set, a Petri plate containing PDA medium with the requisite amount of distilled water instead of a fungicide or a plant extract was added then agar disc with mycelia of each test pathogen was inoculated in the centre of Petri plate. Three replications were maintained for both the experiments and control sets. The inoculated Petri plates were incubated at $25 \pm 2^{\circ} \mathrm{C}$. The radial growth of the colonies of the test pathogens was measured after 5 days of incubation.

The fungitoxicity of the fungicides and plant parts extracts in terms of percentage inhibition of mycelial growth was calculated by using the following formula:

$$
\mathrm{I}=\frac{\mathrm{C}-\mathrm{T}}{\mathrm{C}} \times 100
$$

where, $\mathrm{I}=$ Per cent growth inhibition, $\mathrm{C}=$ Growth in control, $\mathrm{T}=$ Growth in treatment.

The results were statistically analyzed by " $t$ " test following Steel and Torrie (1960). 


\section{RESULTS AND DISCUSSION}

Three pathogenic fungi Colletotrichum gloeosporioides (Penz.) Sacc., Fusarium nivale (Fr.) Ces., and Fusarium sp. were isolated from infected papaya fruits. Five fungicides viz., Autostin 50 WDG, Dithane M 45, Greengel 72 WP, Ridomil Gold MZ 68 WG and Tilt 250 EC were selected to evaluate in vitro efficacy at 100 , 200, 300, 400 and $500 \mathrm{ppm}$ concentrations against three pathogenic fungi. ppm and 500 ppm concentrations. Greengel 72 WP and Ridomil 68 WG showed complete growth inhibition of the fungus at $500 \mathrm{ppm}$ respectively. The toxicity of these fungicides against C. gloeosporioides at $100 \mathrm{ppm}$ in descending order was Autostin $50 \mathrm{WDG}=$ Tilt 250 EC> Greengel 72 WP> Ridomil Gold MZ 68 WG> Dithane M 45 (Table 1).

On the other hand, complete inhibition of the growth of Fusarium nivale was observed with

Table 1. Per cent inhibition of radial growth of Colletotrichum gloeosporioides at different concentrations of fungicides

\begin{tabular}{|c|c|c|c|c|c|}
\hline \multirow[t]{2}{*}{ Name of fungicides } & \multicolumn{5}{|c|}{$\%$ inhibition of radial growth at different concentrations (ppm) } \\
\hline & 100 & 200 & 300 & 400 & 500 \\
\hline Autostin $50 \mathrm{WDG}$ & $100^{\mathrm{a}}$ & $100^{\mathrm{a}}$ & $100^{\mathrm{a}}$ & $100^{\mathrm{a}}$ & $100^{\mathrm{a}}$ \\
\hline Dithane M-45 & $51.21^{\mathrm{b}}$ & $56.91^{\mathrm{b}}$ & $67.47^{\mathrm{a}}$ & $100^{\mathrm{a}}$ & $100^{\mathrm{a}}$ \\
\hline Greengel $72 \mathrm{WP}$ & $60.97^{\mathrm{b}}$ & $66.67^{\mathrm{a}}$ & $68.29^{\mathrm{a}}$ & $78.04^{\mathrm{a}}$ & $100^{\mathrm{a}}$ \\
\hline $\begin{array}{l}\text { Ridomil Gold MZ } 68 \\
\text { WG }\end{array}$ & $55.28^{\mathrm{b}}$ & $60.97^{\mathrm{b}}$ & $70.73^{\mathrm{a}}$ & $81.30^{\mathrm{a}}$ & $100^{\mathrm{a}}$ \\
\hline Tilt $250 \mathrm{EC}$ & $100^{\mathrm{a}}$ & $100^{\mathrm{a}}$ & $100^{\mathrm{a}}$ & $100^{\mathrm{a}}$ & $100^{\mathrm{a}}$ \\
\hline
\end{tabular}

$\mathrm{a}, \mathrm{b}$ and $\mathrm{c}$ indicate significance of ' $\mathrm{t}$ ' value at $\mathrm{p}=0.001$ and 0.01 and 0.05 , respectively.

In a row, figures with same letter do not differ significantly, whereas figures with dissimilar letter differ significantly (as per DMRT), NS = Not significant. Efficiency gradient of fungicides against Colletotrichum gloeosporioides at 100 ppm concentration: Autostin 50 WDG=Tilt 250 EC> Greengel 72 WP> Ridomil Gold MZ 68 WG> Dithane M 45.

In the present investigation, complete inhibition of the radial growth of $C$. gloeosporioides was observed with Autostin 50 WDG and Tilt 250 $\mathrm{EC}$ at all the concentrations used. Among the fungicides, Dithane M 45 showed complete growth inhibition of C. gloeosporioides at 400
Autostin 50 WDG at all the concentrations used. Tilt 250 EC showed $100 \%$ growth inhibition of the fungus at $400 \mathrm{ppm}$ and $500 \mathrm{ppm}$ concentrations. Ridomil gold MZ 68 WG, Dithane M 45 and Greengel 72 WP showed highest $78.02 \%, 71.42 \%$ and $70.32 \%$ growth

Table 2. Per cent inhibition of radial growth of Fusarium nivale at different concentrations of fungicides Name of fungicides $\%$ inhibition of radial growth at different concentrations (ppm)

\begin{tabular}{|c|c|c|c|c|c|}
\hline & 100 & 200 & 300 & 400 & 500 \\
\hline Autostin $50 \mathrm{WDG}$ & $100^{\mathrm{a}}$ & $100^{\mathrm{a}}$ & $100^{\mathrm{a}}$ & $100^{\mathrm{a}}$ & $100^{\mathrm{a}}$ \\
\hline Dithane M-45 & $58.24^{b}$ & $60.43^{\mathrm{a}}$ & $64.83^{\mathrm{a}}$ & $69.23^{\mathrm{a}}$ & $71.42^{\mathrm{a}}$ \\
\hline Greengel $72 \mathrm{WP}$ & $51.64^{b}$ & $56.04^{b}$ & $58.24^{\mathrm{a}}$ & $64.83^{\mathrm{a}}$ & $70.32^{\mathrm{a}}$ \\
\hline $\begin{array}{l}\text { Ridomil Gold MZ } \\
68 \mathrm{WG}\end{array}$ & $59.34^{\mathrm{b}}$ & $62.63^{\mathrm{a}}$ & $63.29^{\mathrm{a}}$ & $67.03^{\mathrm{a}}$ & $78.02^{\mathrm{a}}$ \\
\hline Tilt $250 \mathrm{EC}$ & $86.90^{\mathrm{a}}$ & $93.78^{\mathrm{a}}$ & $98.20^{\mathrm{a}}$ & $100^{\mathrm{a}}$ & $100^{\mathrm{a}}$ \\
\hline
\end{tabular}

$\mathrm{a}, \mathrm{b}$ and $\mathrm{c}$ indicate significance of ' $\mathrm{t}$ ' value at $\mathrm{p}=0.001,0.01$ and 0.05 , respectively.

In a row, figures with same letter do not differ significantly, whereas figures with dissimilar letter differ significantly (as per DMRT), NS = Not significant. Efficiency gradient of fungicides against Fusarium nivale at $100 \mathrm{ppm}$ concentration: Autostin $50 \mathrm{WDG}=$ Tilt 250 EC>Ridomil Gold MZ 68 WG> Dithane M45>Greengel 72 WP. 
inhibition of Fusarium nivale, respectively at $500 \mathrm{ppm}$. The toxicity of these fungicides against Fusarium nivale at $100 \mathrm{ppm}$ in descending order was Autostin 50 WDG> Tilt 250 EC> Ridomil Gold MZ 68 WG> Dithane M 45> Greengel 72 WP (Table 2).

Complete inhibition of the growth of Fusarium sp. was observed with Autostin 50 WDG, at all concentrations used. Tilt 250 EC showed 100\% growth inhibition of the test fungi at $300 \mathrm{ppm}$, $400 \mathrm{ppm}$ and $500 \mathrm{ppm}$ concentrations. Dithane M 45 showed highest $99.50 \%$ growth inhibition of Fusarium sp. at the $500 \mathrm{ppm}$ concentration. At 500 ppm concentration Ridomil 68 WG and Greengel 72 WP showed complete inhibition of Fusarium sp. The toxicity of these fungicides against Fusarium sp. at $100 \mathrm{ppm}$ in descending order was Autostin 50 WDG> Tilt 250 EC> Dithane M-45> Greengel 72 WP> Ridomil Gold MZ 68 WG (Table 3). due to selection of different test pathogens. Efficacy gradients observed in the present study expressed that Autostin 50 WDG, Tilt 250 EC, Dithane M-45, Greengel 72 WP and Ridomil 68 WG were the best inhibiting agent against the in vitro growth of the test pathogens. In contrast to the present study, Chakraborty et al. (2009) reported that, at $0.5 \%$ dose, Bavistin happened to be the most efficient with the highest inhibition (83.7\%) of growth of Fusarium solani causing wilt of brinjal in vitro. Bashar (1992) while reporting the results of laboratory evaluation of some pesticides on F. oxysporum f. sp. Ciceri causing wilt of chick pea found that Bavistin checked the growth of the pathogen completely at $100 \mathrm{ppm}$. Bashar also noted that Dithane M 45

Table 3. Per cent inhibition of radial growth of Fusarium sp. at different concentrations of fungicides

\begin{tabular}{lccccc}
\hline Name of fungicides & \multicolumn{5}{c}{$\%$ inhibition of radial growth at different concentrations (ppm) } \\
\cline { 2 - 5 } & 100 & 200 & 300 & 400 & 500 \\
\hline Autostin 50 WDG & $100^{\mathrm{a}}$ & $100^{\mathrm{a}}$ & $100^{\mathrm{a}}$ & $100^{\mathrm{a}}$ & $100^{\mathrm{a}}$ \\
Dithane M-45 & $78.30^{\mathrm{a}}$ & $84.90^{\mathrm{a}}$ & $86.79^{\mathrm{a}}$ & $90.00^{\mathrm{a}}$ & $99.5^{\mathrm{a}}$ \\
Greengel 72 WP & $75.47^{\mathrm{a}}$ & $81.13^{\mathrm{a}}$ & $82.07^{\mathrm{a}}$ & $82.07^{\mathrm{a}}$ & $100^{\mathrm{a}}$ \\
Ridomil Gold MZ 68 & $46.22^{\mathrm{b}}$ & $74.52^{\mathrm{a}}$ & $81.13^{\mathrm{a}}$ & $98.70^{\mathrm{a}}$ & $100^{\mathrm{a}}$ \\
WG & & & & $100^{\mathrm{a}}$ & $100^{\mathrm{a}}$ \\
Tilt 250 EC & $95.80^{\mathrm{a}}$ & $99.90^{\mathrm{a}}$ & $100^{\mathrm{a}}$ &
\end{tabular}

$a, b$ and $c$ indicate significance of ' $t$ ' value at $p=0.001,0.01$ and 0.05 , respectively. In a row, figures with same letter do not differ significantly, whereas figures with dissimilar letter differ significantly (as per DMRT), NS = Not significant. Efficiency gradient of fungicides against Fusarium sp. at 100 ppm concentration: Autostin 50 WDG> Tilt 250 EC> Dithane M-45>Greengel 72 WP>Ridomil Gold MZ 68 WG

Efficacy of various fungicides against the three test fungi pathogens indicates that Autostin 50 WDG, Tilt 250 EC, Dithane M-45, Greengel 72 WP and Ridomil 68 WG showed promising results. The same fungicides also showed different effects on three test pathogens in the present investigation. This variation might be failed to check the growth of the pathogen completely even at 3,000 ppm.

All the fungicides tested caused partial or complete inhibition of $C$. gloeosporioides, $F$. nivale and Fusarium sp. at $500 \mathrm{ppm}$ concentration (Tables 1-3). Similar observations have also been reported for other fungicides by 
Vishwakarma and Chaudhury (1992) and Bashar (1992). Singh and Singh (1970) observed that reaction of Fusarium spp. to fungicides varies from species to species and sometimes even from isolate to isolate of the same species. It was reported by Chowdhury et al. (2015) that Dithane, Ridomil and Bavistin at 400 and 500 ppm showed complete inhibition of radial growth of $F$. moniliforme.

Results of plant extracts on the radial growth of Colletotrichum gloeosporioides, Fusarium nivale and Fusarium sp. are presented in Tables 4-6. All the plant extracts showed varied degree followed by Curcuma longa (84.00\%), Azadirachta indica (82.79\%), Adhatoda vasica $(80.99 \%)$, Thuja orientalis $(71.00 \%)$, Lantana camara $(67.32 \%)$, Tagetes erecta $(65.59 \%)$ and Vitex nigundo (42.77\%). The inhibition of the pathogen increases with increase in concentration of plant extracts in culture medium. The order of effectiveness against $C$. gloeosporioides at $20 \%$ concentration was Ocimum sanctum $>\quad$ Curcuma longa> Azadirachta indica> Adhatoda vasica $>$ Thuja orientalis $>$ Lantana camara $>$ Tagetes erecta> Vitex negundo (Table 4).

Table 4. Effects of plant extracts on the radial growth of Colletotrichum gloeosporioides at different concentrations

\begin{tabular}{lcccc}
\hline \multirow{2}{*}{ Name of plants } & \multicolumn{4}{c}{ \% inhibition of radial growth of the pathogen at different concentrations (\%) } \\
\cline { 2 - 5 } & 5 & 10 & 15 & 20 \\
\hline Adhatoda vasica & $51.78^{\mathrm{b}}$ & $62.77^{\mathrm{b}}$ & $78.23^{\mathrm{a}}$ & $80.99^{\mathrm{a}}$ \\
Azadirachta indica & $54.78^{\mathrm{b}}$ & $70.45^{\mathrm{a}}$ & $77.84^{\mathrm{a}}$ & $82.79^{\mathrm{a}}$ \\
Curcuma longa & $50.00^{\mathrm{b}}$ & $52.50^{\mathrm{b}}$ & $67.50^{\mathrm{a}}$ & $84.00^{\mathrm{a}}$ \\
Lantana camara & $40.34^{\mathrm{c}}$ & $48.99^{\mathrm{b}}$ & $56.20^{\mathrm{b}}$ & $67.32^{\mathrm{b}}$ \\
Ocimum sanctum & $62.23^{\mathrm{b}}$ & $50.14^{\mathrm{b}}$ & $71.28^{\mathrm{a}}$ & $88.57^{\mathrm{a}}$ \\
Tagetes erecta & $31.18^{\mathrm{c}}$ & $49.46^{\mathrm{b}}$ & $48.38^{\mathrm{b}}$ & $65.59^{\mathrm{b}}$ \\
Thuja orientalis & $27.66^{\mathrm{c}}$ & $32.65^{\mathrm{b}}$ & $65.22^{\mathrm{a}}$ & $71.00^{\mathrm{a}}$ \\
Vitex nigundo & $18.98^{\mathrm{NS}}$ & $36.70^{\mathrm{c}}$ & $39.24^{\mathrm{b}}$ & $42.77^{\mathrm{b}}$ \\
\hline
\end{tabular}

$\mathrm{a}, \mathrm{b}$ and $\mathrm{c}$ indicate significance of ' $\mathrm{t}$ ' value at $\mathrm{p}=0.001,0.01$ and 0.05 , respectively. In a row, figures with same letter do not differ significantly, whereas figures with dissimilar letter differ significantly (as per DMRT), NS $=$ Not significant. Efficiency gradient of plant extracts against Colletotrichum gloeosporioides at $20 \%$ concentration: cimum sanctum $>$ Curcuma longa $>$ Azadirachta indica $>$ Adhatoda vasica $>$ Thuja orientalis $>$ Lantana camara $>$ Tagetes erecta> Vitex negundo.

of growth inhibition of the pathogens at different concentrations. Out of the eight plant extracts, Ocimum sanctum $(88.57 \%)$ showed best results for inhibition of radial growth of Colletotrichum gloeosporioides at $20 \%$ concentration which was
Chowdhury et al. (2015) reported that ethanol extract of $A$. indica showed complete radial growth inhibition of at 10 and $20 \%$ concentration whereas $T$. erecta showed complete growth inhibition at $20 \%$ concentrations. Prasad and Anamika (2015) 
reported that extracts of $L$. camara were found most effective for the control of the $C$. gloeosporioides. Imtiaj et al. (2005) found that plant extracts such as Curcuma longa, T. erecta and Zingeber officinale were also highly effective against $C$. gloeosporioides.

Out of the eight plant extracts, Curcuma longa showed highest $(88.55 \%)$ radial growth inhibition of Fusarium nivale at $20 \%$ concentration which was followed by Ocimum sanctum (87.65\%), Azadirachta indica (75.64\%), Tagetes erecta (69.09\%), Lantana camara (57.78\%), Adhatoda vasica $(56.79 \%)$, Vitex negundo $(49.03 \%)$ and Thuja orientalis $(47.00 \%)$. The inhibition of the pathogen increases with the increase of the concentration of the plant extracts in culture medium (Table-5).

The order of effectiveness against Fusarium nivale at $20 \%$ concentration was Curcuma longa $>$ Ocimum sanctum $>$ Azadirachta indica $>$ Tagetes erecta $>$ Lantana camara $>$ Adhatoda vasica> Vitex negundo> Thuja orientalis (Table 5). Out of the eight plant extracts, Azadirachta indica showed highest (90.19\%) radial growth inhibition of Fusarium sp. at $20 \%$ concentration which was followed by Adhatoda vasica (80.02\%), Ocimum sanctum (79.89\%), Thuja orientalis (69.34\%), Lantana camara (67.99\%), Cucurma longa (67.64), Tagetes erecta $(65.93 \%)$ and Vitex negundo (58.75\%). The inhibition of the pathogen increases with the increase of the concentration of the plant extracts in culture medium. The order of effectiveness against Fusarium sp. at $20 \%$ concentration was Azadirachta indica> Adhatoda vasica $>$ Ocimum sanctum $>$ Thuja orientalis> Lantana camara $>$ Cucurma longa $>$ Tagetes erecta $>$ Vitex negundo (Table 6). In contrast to the present study, Bashar and Chakma (2014) reported that the plant extract of $A$. indica showed $62.03 \%$ growth inhibition of $F$. oxysporum at $20 \%$ concentration. The same plant extracts also showed different effects on different pathogens in the present investigation. This variation might be due to selection of different test pathogens. Singh et al. (1993) reported the effectiveness of aqueous extracts of $A$. indica in the control of disease development in banana. Plant

Table 5. Effects of plant extracts on the radial growth of Fusarium nivale at different concentrations

\begin{tabular}{lcccc}
\hline \multirow{2}{*}{ Name of plants } & \multicolumn{4}{c}{$\%$ inhibition of radial growth of the pathogen at different concentrations $(\boldsymbol{\%})$} \\
\cline { 2 - 5 } & 5 & 10 & 15 & 20 \\
\hline Adhatoda vasica & $32.78^{\mathrm{c}}$ & $45.66^{\mathrm{b}}$ & $45.66^{\mathrm{b}}$ & $56.79^{\mathrm{b}}$ \\
Azadirachta indica & $40.45^{\mathrm{c}}$ & $55.67^{\mathrm{b}}$ & $65.54^{\mathrm{a}}$ & $75.64^{\mathrm{a}}$ \\
Curcuma longa & $69.44^{\mathrm{b}}$ & $72.22^{\mathrm{a}}$ & $79.00^{\mathrm{a}}$ & $88.55^{\mathrm{a}}$ \\
Lantana camara & $26.90^{\mathrm{c}}$ & $30.33^{\mathrm{c}}$ & $56.44^{\mathrm{b}}$ & $57.78^{\mathrm{b}}$ \\
Ocimum sanctum & $38.27^{\mathrm{c}}$ & $67.90^{\mathrm{b}}$ & $70.37^{\mathrm{a}}$ & $87.65^{\mathrm{a}}$ \\
Tagetes erecta & $36.36^{\mathrm{c}}$ & $63.63^{\mathrm{b}}$ & $56.81^{\mathrm{b}}$ & $69.09^{\mathrm{b}}$ \\
Thuja orientalis & $30.12^{\mathrm{NS}}$ & $35.22^{\mathrm{c}}$ & $45.50^{\mathrm{c}}$ & $47.00^{\mathrm{c}}$ \\
Vitex negundo & $18.75^{\mathrm{NS}}$ & $31.25^{\mathrm{c}}$ & $47.50^{\mathrm{c}}$ & $49.03^{\mathrm{b}}$ \\
\hline
\end{tabular}

$\mathrm{a}, \mathrm{b}$ and $\mathrm{c}$ indicate significance of ' $\mathrm{t}$ ' value at $\mathrm{p}=0.001,0.01$ and 0.05 , respectively. In a row, figures with same letter do not differ significantly, whereas figures with dissimilar letter differ significantly (as per DMRT), NS = Not significant. Efficiency gradient of plant extracts against Fusarium nivale at 20\% concentration: Curcuma longa $>$ Ocimum sanctum $>$ Azadirachta indica $>$ Tagetes erecta $>$ Lantana camara $>$ Adhatoda vasica $>$ Vitex negundo> Thuja orientalis. 
Table 6. Effects of plant extracts on the radial growth of Fusarium sp. at different concentrations

\begin{tabular}{lcccc}
\hline \multirow{2}{*}{ Name of plants } & \multicolumn{4}{c}{ \% inhibition of radial growth of the pathogen at different concentrations (\%) } \\
\cline { 2 - 5 } & 5 & 10 & 15 & 20 \\
\hline Adhatoda vasica & $66.50^{\mathrm{b}}$ & $69.45^{\mathrm{b}}$ & $75.78^{\mathrm{a}}$ & $80.02^{\mathrm{a}}$ \\
Azadirachta indica & $58.92^{\mathrm{b}}$ & $75.27^{\mathrm{b}}$ & $82.25^{\mathrm{a}}$ & $90.19^{\mathrm{a}}$ \\
Cucurma longa & $58.82^{\mathrm{b}}$ & $61.76^{\mathrm{a}}$ & $64.70^{\mathrm{a}}$ & $67.64^{\mathrm{a}}$ \\
Lantana camara & $29.77^{\mathrm{c}}$ & $34.46^{\mathrm{b}}$ & $58.92^{\mathrm{a}}$ & $67.99^{\mathrm{a}}$ \\
Ocimum sanctum & $43.15^{\mathrm{c}}$ & $53.68^{\mathrm{b}}$ & $64.21^{\mathrm{b}}$ & $79.89^{\mathrm{a}}$ \\
Tagetes erecta & $24.57^{\mathrm{b}}$ & $34.74^{\mathrm{b}}$ & $54.91^{\mathrm{a}}$ & $65.93^{\mathrm{a}}$ \\
Thuja orientalis & $32.14^{\mathrm{c}}$ & $45.67^{\mathrm{b}}$ & $56.88^{\mathrm{b}}$ & $69.34^{\mathrm{a}}$ \\
Vitex negundo & $27.02^{\mathrm{b}}$ & $37.50^{\mathrm{a}}$ & $46.25^{\mathrm{a}}$ & $58.75^{\mathrm{a}}$ \\
\hline
\end{tabular}

$\mathrm{a}, \mathrm{b}$ and $\mathrm{c}$ indicate significance of ' $\mathrm{t}$ ' value at $\mathrm{p}=0.001,0.01$ and 0.05 , respectively. In a row, figures with same letter do not differ significantly, whereas figures with dissimilar letter differ significantly (as per DMRT), NS = Not significant. Efficiency gradient of plant extracts against Fusarium sp. at 20\% concentration: Azadirachta indica $>$ Adhatoda vasica $>$ Ocimum sanctum $>$ Thuja orientalis $>$ Lantana camara $>$ Cucurma longa $>$ Tagetes erecta> Vitex negundo

parts and their constituents of some higher plants have already been reported to be of successful nature of fungitoxicants, lesser phytotoxicity, systemicity, easy biodegradability and favourable effects of the growth of the host (Fawcett and Spencer 1970, Panday et al. 1983). Chakraborty et al. (2009) reported the efficacy of various cell free extracts of the plants against the growth inhibition of the pathogen. The effectiveness of extracts varied significantly with dosage, where $100 \%$ inhibition of the pathogen was achieved both with neem and garlic extracts.

\section{ACKNOWLEDGEMENT}

The authors wish to express gratitude to the Ministry of Science and Technology, People's Republic of Bangladesh for providing financial assistance through NST fellowship awarded to Rezwana Binte Helal. The authors also wish to thank the Centre for Advanced Research in Sciences (CARS), Dhaka University for providing support to the research during the tenure of the research (2016-2017).

\section{REFERENCES}

Ahmed, N. and K. Sultana. 1984. Fungitoxic effect of garlic on treatment of jute seed. Bangladesh J. Bot. 13(2): 130-136.

Anonymous. 1968. Plant Pathologist Pocket Book. The Commonwealth Mycological Institute, England.pp. 267.

Baker, K. F. 1987. Evolving concepts of biological control of plant pathogens. Annu. Rev. Phytopathol. 25: 67-85

Bashar, M.A. and B, Rai. 1991. Antifungal activity of extracts of some plant parts against Fusarium oxysporum f. sp. ciceri. Bangladesh J. Bot. 20: 219-222.

Bashar, M.A. 1992. Laboratory evaluation of some pesticides on Fusarium oxysporum f. sp. ciceri causing wilt of chickpea. Bangladesh J. Bot. 21(1): 157-159.

Bashar, M.A. and M. Chakma 2014. In vitro control of Fusarium solani and F. oxysporum the causative agent of brinjal wilt. Dhaka Univ. J. Biol. Sci. 23(1): 53-60.

Chakraborty, M.R., N.C. Chatterjee and T.H. Quimio. 2009. Integrated management of fusarial wilt of eggplant (Solanum melongena) with soil solarization. Micologia Aplicada International.

Chowdhury, P., M..A. Bashar and S. Shamsi. 2015. In vitro evaluation of fungicides and plant extracts against pathogenic fungi of two rice varieties. Bangladesh J. Bot. 44(2): 251-259. 
Cook, R.J. 1993. Making greater use of microbial inoculants in agriculture. Amrn. Rev. Phytopathol. 31: 53-80.

Duke JA 1984.Borderline Herbs, CRS Press, Boca Roton Florida,USA.

Fawcett, C.H. and D.M. Spencer. 1970. Plant chemotherapy with natural products. Ann. Rev. Phytopathol. 8: 403-418.

Hassan, M,K. 2010. A guide to postharvest handling of fruits and vegetables, Department of Horticulture. Bangladesh Agricultural University, Mymensingh.

Helal, R.B. 2017. Mycoflora associated with papaya (Carica papaya L.) and their management.. MS thesis. Department of Botany University of Dhaka. Bangladesh pp. $\mathrm{xi}+182$.

Hosen, S., S Shamsi and M.A. Bashar. 2016. In vitro efficacy of fungicides and plant extracts on the growth of Colletotrichum gloeosporioides (Penz.) Penz. \& Sacc. And Sclerotium rolfsii Sacc. the causal organisms of anthracnose and soft rot of jute. Dhaka Univ. J. Bio. Sci. 25(2): 195-199.

Imtiaj, A., S.A. Rahman, S. Alam, R. Parvin, K. M., Farhana, S.B. Kim, T. S. Lee. 2005. Effect of Fungicides and Plant Extracts on the Conidial Germination of Colletotrichum gloeosporioides causing mango anthracnose. Mycobiology. 33(4): 200-205.

Heydari, A. and M. Pessarakli, 2010. A review on biological control of fungal plant pathogens using microbial antagonists. Journal of Biological Sciences 10(4): 203-290.

Islam, M. A., S. Shamsi, S. Hosen and M. A. Bashar. 2017. In vitro effect of five plant extracts and five fungicides on Fusarium oxysporum Schlecht. and $F$. solani (Mart.) Sacc. causal agent of brinjal (Solanum melongena L.) wilt. Dhaka Univ. J. Bio. Sci. 26(1): 39-44.

Miah, M.A., T. Ahmed, N. R. Sharma, A. Ali and S.A. Miah. 1990. Antifungal activity of some plant extracts. Bangladesh J. Bot. 19: 5-10.
Milind, P. and Gurditta. 2011. Busketful benefits of papaya. International Research Journal of Pharmacy. 2(7): 6-12.

Mondal, M.F., M.A. Rahman and M.A.J. Pramanik. 1995. Effect of different post harvest treatments on physio - chemical changes and shelf life of mango. Bangladesh horticulture. 23(1\&2): 1-5.

Monoharachary, C. and M.M. Reddy. 1978. Efficacy of some leaf extracts on Botryodiplodia theobromae Pat. Geobios. 5(4): 190-191.

Panday, D.K., H. Chandra, N.N. Tripathi and Dixit 1983. Fungitoxicity of some higher plants with special reference to the synergistic activity among some fungitoxicants. Phytopathol. Z. 106: 226-232.

Parni, B. and Y. Verma. 2014. Biochemical properties in peel, pulp and seeds of Carica papaya. Plant Archives 14(1): 565-568.

Prasad, R,R. and Anamika. 2015. Effects of plant leaf extract against Colletotrichum gloeosporioides (Penz) Sac. Causing postharvest Disease of Papaya. Journal of Agricultural Science 7(5): 195-198.

Sawant, S.G. and D.U. Gawai. 2011. Effect of fungal infections on nutritional value of papaya fruits, Curr. Bot. 2(1): 43-44.

Singh N and Singh RS 1970. Development of wilt causing species of Fusarium in fungicide treated soils. Indian Phytopath. 23: 545-552.

Singh HNP, Prasad MM and Sinha KK 1993. Efficacy of leaf extracts of some medicinal plants against disease development in banana. Letters in Applied Microbiology 17: 269-271.

Steel. R. G. D. and J. H. Torrie. 1960. Principles and Procedures of Statistics. MacGraw Hill Book Co., New York. pp. xvi +481.

Vishwakarma, S. N. and K. C. B. Chaudhury 1992. Laboratory evaluation of some fungicides against some root rot disease pathogens of gram. Phytopath. 35: 624-627.

(Received revised manuscript on 23 September 2018) 